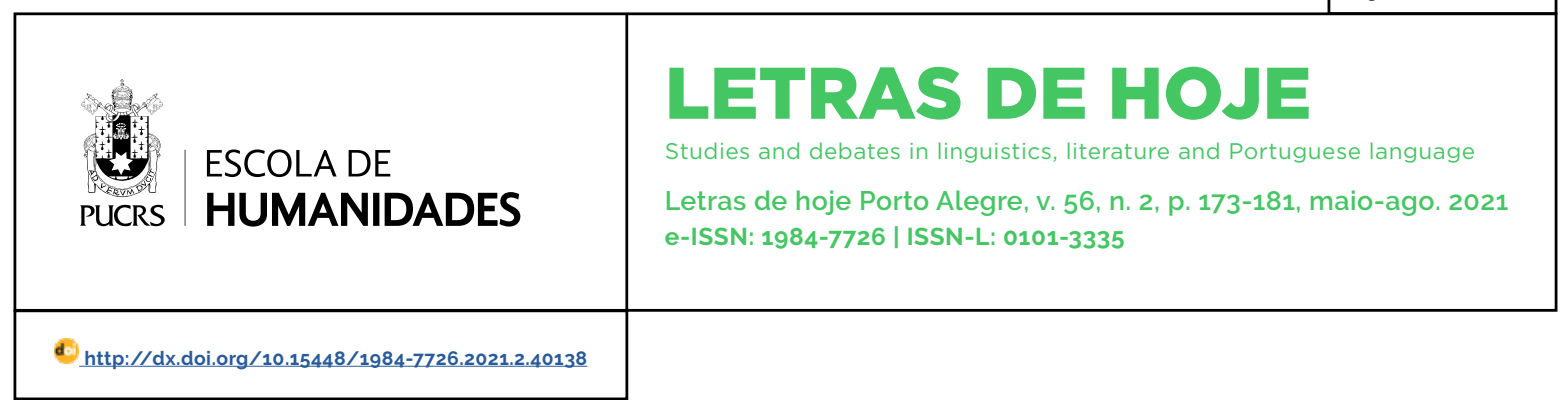

SEÇÃO: O CONTO BRASILEIRO CONTEMPORÂNEO DE AUTORIA FEMININA

\title{
O conto autoficcional de Veronica Stigger
}

\author{
Veronica Stigger's autofictional tale \\ El cuento autoficticio de Veronica Stigger
}

\section{Bruna Fontes Ferraz ${ }^{1}$ orcid.org/0000-0002-9136-6838 bruna.fferraz@gmail.com}

Recebido em: 14 fev. 2021 Aprovado em: 20 maio 2021 Publicado em: 9 nov. 2021
Resumo: Este texto visa refletir sobre o conto autoficcional de Veronica Stigger, evidenciando como a autora supera esse conceito ao constatar o seu desgaste na literatura contemporânea. Para isso, analisaremos três contos de Stigger: "O livro", publicado em Sombrio Ermo Turvo, "Imagem verdadeira" e "200 m², publicados em Os anões, textos que se apresentam como paródias da autoficção e que ressaltam como a escritora gaúcha, ao transmutar-se em personagem, distorce sua própria imagem, em um processo especular de seus textos e da própria autoria. Ao considerarmos as caracteristicas do conto contemporâneo e as especificidades do conto de Stigger, procuramos evidenciar, tomando como aporte teórico, sobretudo, os estudos sobre autoficção de Vicent Colonna e os ensaios sobre os espelhos de Umberto Eco, como Stigger forja vidas inusitadas para si para mostrar que tudo é ficção.

Palavras-chave: Conto contemporâneo. Autoficção. Veronica Stigger.

Abstract: This text aims to reflect on the autofictional tale of Veronica Stigger, showing how the author overcomes this concept when verifying its wear in contemporary literature. For this, we will analyze three short stories by Stigger: "The book", published in Sombrio Ermo Turvo, "True image" and "200 m²", published in Os anões, texts that present themselves as parodies of autofiction. Thus the writer, when transmuting herself into a character, distorts her own image, in a specular process of her texts and authorship. When considering the characteristics of the contemporary tale and the specificities of Stigger's tale, we seek to highlight, taking as a theoretical contribution, above all, the studies on Vicent Colonna's autofiction and the essays on Umberto Eco's mirrors, as Stigger forges unusual lives for herself for show that everything is fiction.

Keywords: Contemporary tale. Autofiction. Veronica Stigger.

Resumen: Este texto pretende reflexionar sobre el cuento autoficticio de Veronica Stigger, mostrando cómo la autora supera este concepto al comprobar su desgaste en la literatura contemporánea. Para ello analizaremos tres cuentos de Stigger: "El libro", publicado en Sombrio Ermo Turvo, "Imagen verdadera" y "200 m²", publicados en Os anões, textos que se presentan como parodias de la autoficción. Así la escritora, al transmutarse en personaje, distorsiona su propia imagen, en un proceso especular de sus textos y autoria. Al considerar las características del cuento contemporáneo y las especificidades del cuento de Stigger, buscamos destacar, tomando como aporte teórico, sobre todo, los estudios sobre la autoficción de Vicent Colonna y los ensayos sobre los espejos de Umberto Eco, como Stigger forja vidas insólitas para demostrar que todo es ficción.

Palabras clave: Cuento contemporáneo. Autoficción. Veronica Stigger. 
"O homem não é mais artista, tornou-se obra de arte".

(Niestzsche)

\section{O conto de Veronica Stigger: considerações iniciais}

A escritora brasileira Veronica Stigger vem se destacando no cenário nacional, sobretudo, como contista, ${ }^{2}$ dada a sua predileção pela narrativa curta, na qual consegue manter um certo tipo de ritmo e de tensão característicos da própria ficção brasileira contemporânea. Transgressora, Stigger desmonta e fragmenta gêneros textuais, em uma proposta formal e linguistica experimental, para criar. Tal como a arte cubista, suas narrativas breves parecem quebra-cabeças, cujas peças foram montadas aleatoriamente, constituindo-se como uma imagem deformada. Assim, a escritora gaúcha rompe com a forma e com a norma, pretendendo, apenas, jogar, brincar e perverter a língua e os gêneros. Em entrevista concedida a Bruno Dorigatti, a autora afirma: "Gosto de experimentar gêneros diferentes, de desrespeitar propositalmente os limites dos gêneros. Não acredito na estabilidade da forma literária, fixada em gêneros bem definidos, como o conto, 0 poema, a novela, o romance" (STIGGER [2010] apud SOUZA, 2016, p. 521).

O conto de Stigger, nesse sentido, apresenta-se como um texto hibrido, como se pretende mostrar ao longo deste artigo, no qual características de outros gêneros, como o teatro, a palestra, documentos oficiais, por exemplo, emprestam sua forma para a constituição desses "objetos verbais não identificados", tal como Flora Süssekind ([2013]) classifica a literatura contemporânea, apropriando-se da expressão de Christophe Hanna. A narrativa curta é um espaço potencialmente aberto para a inovação e a criação dada a sua caracteristica de condensar as mais variadas formas da ficção: "Proteiforme, o conto não só consegue abraçar a temática toda do romance, como põe em jogo os princípios de composição que regem a escrita moderna em busca do texto sintético e do convívio de tons, gêneros e significados" (BOSI, 2015, p. 7).

A hibridização de gêneros textuais não é, no entanto, um aspecto exclusivo à ficção de Stigger: certamente essa caracteristica anuncia-se como um aspecto do conto contemporâneo, como apontado por Karl Erik Schøllhammer que, em Ficção brasileira contemporânea (2009), acrescenta, a essa tendência, as formas ultracurtas, as estruturas fragmentadas e "o hibridismo crescente entre a escrita literária e a não literária, seja jornalistica e pública, seja pessoal e intima" (2009, p. 14).

Embora também inserida nessa tendência, a prosa de Stigger vai se deslocando, ultrapassando limites e borrando fronteiras na constituição de um gênero que, se engloba todas as características que marcam o conto contemporâneo, é para extrapolá-las. Segundo Ricardo Piglia, em suas "Novas teses sobre o conto", "A arte de narrar é uma arte da duplicação" (PIGLIA, 2004. p. 114). Assim, ciente de que "um conto sempre conta duas histórias" (PIGLIA, 2004, p. 89), tal como define Piglia em "Teses sobre o conto", e que o paradoxo e a ambiguidade marcam sua estrutura, Stigger leva às últimas consequências a ideia do desdobramento: seus contos são como espelhos, nos quais encontramos livros dentro de livros, assim como a representação da própria autora, que insere seu nome próprio na narrativa, tornando-se personagem de sua trama.

Projetar-se a si mesma, ficcionalizar-se: essa é uma característica que tem se apresentado em alguns contos da autora, que parece usar a técnica da autoficção na construção do que poderiamos chamar de uma espécie de "conto narcisico". Mas, ao levar seu nome próprio para o cerne da narrativa, a escritora gaúcha, perversamente, brinca com os limites entre verdade e mentira, evidenciando que "Projetar-se para além do fim, para perceber o sentido, é algo impossivel de se conseguir, salvo sob a forma

2 Dos dez livros já publicados por Veronica Stigger, todos são livros de contos, à exceção de Opisanie świata, seu primeiro romance, publicado pela Cosac Naify em 2013; e os infantis Dora e o sol, publicado pela Editora 34, em 2010, e Onde a onça bebe água, em coautoria com Eduardo Viveiros de Castro, publicado em 2015 pela Cosac Naify. 
da arte" (PIGLIA, 2004, p. 105). Ao desdobrar-se em personagem, Stigger transforma seu conto em um espelho deformante, distorcendo, assim, tanto a narrativa quanto a si mesma. Desse modo, em sua contística, a noção de limite definha: realidade e ficção, vida e arte, biografia e autoficção misturam-se de tal forma que o narrador insere, na trama, pistas falsas, levando o leitor desatento a uma leitura equivocada dos sinais.

É, portanto, com o objetivo de investigar as características do conto autoficcional de Veronica Stigger, seus contos narcísicos, que este trabalho se propõe. Para isso, tomaremos como escopo de investigação os contos "O livro", publicado em sua obra mais recente, Sombrio Ermo Turvo, de 2019 , e "Imagem verdadeira" e "200 m²", publicados em Os anões, de 2010.

\section{Os contos narcísicos de Veronica Stigger}

Em seu mais recente livro, Sombrio Ermo Turvo, publicado pela editora Todavia, em 2019, Veronica Stigger, por meio de uma jocosa brincadeira, ficcionaliza a si mesma, tendência, aliás, que já se mostrava presente em outros contos, como "200 m" e "Imagem verdadeira", publicados em Os anões. Em "O livro", primeiro conto da seção "Scherzo grazioso" de Sombrio Ermo Turvo, encontramos o nome da escritora Veronica Stigger no centro do texto para designar uma personagem. O tom cômico do conto, já insinuado no título italiano da seção, adquire nuances teóricas explicitadas pela voz do narrador, um teórico da literatura, cuja especialidade é justamente a obra da personagem Veronica Stigger.

Narrado em primeira pessoa por essa voz professoral, o conto "O livro" apresenta várias características do conto contemporâneo como, sobretudo, a hibridização de gêneros textuais. O texto é escrito respeitando a forma de uma palestra proferida oralmente para uma plateia, mesclando indícios reais aos ficcionais, de modo a confundir o leitor (nós, leitores empíricos, e não os ouvintes da palestra fictícia) que, em alguns momentos, derrapa ante o pacto ficcional instituido em toda relação de leitura literária e tende a crer naquela fantasiosa invenção, pois, nesse conto, a obra da personagem Veronica Stigger tende a se confundir com a obra da autora de carne e osso. No entanto, a palestra fictícia versa sobre um livro imaginário, Rancho, jamais escrito pela autora, mas deixado pela escritora personagem. após o seu desaparecimento, ao narrador:

\begin{abstract}
Sete dias depois de seu sumiço, chegou ao meu endereço um envelope enviado de Montevidéu, com a data do carimbo ilegivel, contendo um livro feito artesanalmente em tamanho padrão (14×21 centímetros), capa em cartolina amarelo-gema, costurado à mão de maneira grosseira, com linha vermelha, como se pode ver aqui no slide: os pontos são largos, tortos e desiguais. Salta aos olhos a qualidade igualmente pouco refinada da impressão - o que contrasta com o luxo das publicações dos seus livros pela editora Cosac Naify, que encerrou suas atividades em novembro de 2015. Certamente, o volume não foi impresso em gráfica, mas numa impressora comum como as que costumamos ter em casa, muito provavelmente com cartucho recarregado, uma vez que apresenta falhas e riscos, além de soltar tinta. No centro da capa amarelo-gema, lê-se, em maiúsculas e vermelho, corpo 60, itálico, fonte Garamond (Stigger achava Garamond a mais elegante das fontes, ainda mais quando em itálico): Rancho. Logo abaixo, centralizado, em minúsculas e verde, corpo 18 , normal, também Garamond: "Veronica Stigger". E, no pé da página, igualmente em minúsculas e verde, corpo 14, normal, Garamond: "Edições O Satanista" (STIGGER, 2019, p. 45-46).
\end{abstract}

A abordagem da palestra do narrador será a apresentação desse livro imaginário: Rancho, escrito pela fictícia Veronica Stigger. A estratégia da homônima e real escritora ao duplicar-se ecoa um artificio bastante borgeano, pois, tal como Jorge Luis Borges, também ela preferiu, nesse conto, a escrita de notas sobre livros imaginários ao invés de escrevê-los. Segundo o escritor argentino:

Desvario laborioso e empobrecedor o de compor vastos livros; o de explanar em quinhentas páginas uma ideia cuja exposição oral cabe em poucos minutos. Melhor procedimento é simular que estes livros já existem e apresentar um resumo, um comentário (BORGES, 1970, p. XIII).

Stigger, ao que tudo indica, não chega a escrever a obra Rancho, mas, ao simular sua existência, o narrador pode tecer sobre ela um comentário, uma análise, uma interpretação. Nas palavras do próprio narrador: 
Rancho conta a história, em primeira pessoa, de uma mulher, Verônica, que percorre o mundo promovendo apresentações em que ela lê sempre o mesmo texto: um poema longo, em tercetos, dividido em três partes (Stigger sempre se achou muito hegeliana). [..... Retomando o enredo do livro, o poema que Verônica lê pelo mundo tem estrutura narrativa. Intitula-se "O coração dos homens" e rememora um fato que teria ocorrido em sua infância, quando, aos dez anos, fora obrigada, pela professora de inglês, a tomar parte numa encenação de A Branca de Neve e os sete anões. Ela era o espelho. Como se não bastasse ter que assumir esse papel degradante (ela achava que deveria ser a Branca de Neve), acaba menstruando em cena. Pela primeira vez. Era sua menarca (STIGGER, 2019, p. 47).

O conto "O livro" desdobra-se em quatro níveis textuais: em um primeiro momento, temos a escritora real, Veronica Stigger, que escreve o conto "O livro"; em um segundo nível, temos a fictícia escritora, também nomeada Veronica Stigger, que desaparece e envia, para o narrador, uma espécie de crítico literário, uma obra inédita: Rancho; o terceiro nível narra a história de outra escritora, Verônica (que se diferencia das outras apenas pelo acento circunflexo em seu nome), que faz leituras performáticas de um poema narrativo que escreveu, "O coração dos homens"; e, por fim, o quarto nível narrativo revela o enredo desse poema, considerado "autobiográfico" pelo narrador de "O livro", que narra um episódio traumático da infância de Verônica (com acento circunflexo, reparem).

Esse movimento de mise en abyme, para além da inserção de uma história dentro da outra, surpreende pelo desdobramento autoral nele presente: a escritora real desdobra-se em outras três, criando, a cada vez, uma ficção de si em um diálogo intertextual com sua própria produção literária. Cada duplo projetado pela Veronica Stigger real se torna um personagem excêntrico, fora do comum, intensificando a distância com a realidade, ao criar e inventar uma nova história para si. É curioso observar, no entanto, que essa distância com o real é criada justamente pelos "efeitos de real" presentes no texto, para evocarmos o conceito barthesiano. O poema "O coração dos homens", por exemplo, atribuido à personagem Verônica de Rancho, foi escrito por Veronica Stigger em Sul, obra publicada originalmente na Argentina em 2013 e que saiu, no Brasil, em 2016 pela Editora 34.

Do poema narrativo "O coração dos homens", a escritora, para escrever o conto "O livro", apodera-se de seu enredo: poema dividido em três partes, cuja narradora em primeira pessoa relembra sua infância, mais especificamente alguns episódios escolares marcados pela presença de muito sangue, o sangue da menstruação. Esse poema, do qual confundem-se verdade e mentira, foi apropriado pela personagem Veronica Stigger, autora de Rancho, extraindo dele as mesmas desventuras que passam a ser atribuidas à personagem Verônica (com acento circunflexo).

A escritora gaúcha apropria-se, assim, de sua própria obra para fazer o seu "scherzo", afinal o conto "O livro" é uma grande brincadeira, que chama para a cena literária a teoria da autoficção, mesmo que para transformá-la em uma piada. Da imbricação da crítica e da escritora, surge uma paródia sobre o próprio conto autoficcional.

Gênero de difícil classificação, a autoficção conceito criado na década de 1970 por Serge Doubrovsky em referência ao seu romance Fils, mas que, como nos alerta o próprio autor, sempre existiu na prática literária - vem gerando um certo desgaste entre os críticos dado o seu caráter escorregadio. De comum acordo, talvez, apenas a sua característica de inserir o nome próprio do autor no texto ficcional. De todo modo, o termo pareceu preencher uma lacuna que havia no sistema classificatório das narrativas de si, afinal, ao lado de memórias, autobiografias e das escritas intimas em geral, a autoficção apresenta uma singularidade por se tratar, segundo o conceito de Doubrovsky, de uma "Ficção de fatos e acontecimentos estritamente reais" (DOUBROVSKY, 2014, p. 120).

O caráter fictício de um texto verídico: sob esse paradoxo parece se pautar, portanto, a autoficção, distanciando-se cada vez mais da autobiografia. No entanto, para alguns teóricos, como o próprio Doubrovsky, "toda autobiografia participa do romance porque não existe memória completa ou fiável" (DOUBROVSKY, 2014, p. 121). Desse modo, "Toda autobiografia, qualquer que seja sua 'sin- 
ceridade', seu desejo de 'veracidade', comporta sua parte de ficção" (DOUBROVSKY, 2014, p. 122). Concepção refutada por Philippe Lejeune que, embora nos primeiros tempos de sua pesquisa tenha conferido uma forma ficcional à narrativa autobiográfica, depois, em estudos mais maduros, refuta completamente essa ideia, considerando-a um erro grotesco (PIBAROT, 2014, p. 224). Lejeune resgata, assim, a figura do autor, quando esse já havia sido declarado morto por Barthes, devolvendo a ele o seu lugar e a sua autoridade:

[...] escrever o "eu" supõe então o desejo de ser verdadeiro, o que implica a exclusão, a recusa de toda e qualquer forma de ficção. Escrever o "eu" é se engajar em uma grande aventura. Não há coerção mais difícil do que a da autobiografia a partir do momento em que esta é levada a sério. Escrever o "eu" é uma ascese, é preciso conseguir ver as coisas lucidamente, conhecer algo que talvez sejamos os últimos a poder conhecer (LEJEUNE apud PIBAROT, 2014, p. 227).

As interpretações sobre as escritas de si, suas distinções e classificações variam e, por vezes, se contradizem. Nesse jogo, o autor parece levantar dos mortos, mas, talvez, não como quer Lejeune, e sim como um espectro ficcional que se apropria de marcas do ser real. Assim, entra em cena outro teórico, Vincent Colonna, para quem, nas palavras de Doubrovsky, a autoficção é uma "narrativa feita por um autor-narrador-personagem real de aventuras imaginárias" (DOUBROVSKY, 2014, p. 120). Por isso, considerando esse jogo entre as vozes do autor, do narrador e do personagem e a presença fantasmagórica do autor, tomaremos aqui as distinções apresentadas por Vicent Colonna em seu ensaio "Tipologia da autoficção" para refletirmos sobre a estratégia usada por Stigger em seus contos autoficcionais, mesmo que para satirizar tal conceito.

Colonna, ao buscar delimitar as estratégias de "autofabulação", reflete sobre quatro tipos de autoficção: a "autoficção fantástica", a "autoficção biográfica", a "autoficção especular" e a "autoficção intrusiva". Na "autoficção fantástica", o escritor insere-se no próprio texto como em uma autobiografia, porém sem nenhum compromisso com a verossimilhança (COLONNA, 2014, p. 39). Diferente desta, a "autoficção biográfica" permanece mais próxima da verossimilhança, de modo que o autor, ao transformar-se em "herói de sua história", "fabula sua existência a partir de dados reais" (COLONNA, 2014, p. 44). Já a "autoficção especular" é "baseada em um reflexo do autor ou do livro dentro do livro" (COLONNA, 2014, p. 53); o escritor torna-se, assim, um personagem, e a verossimilhança e o realismo são indiferentes, tal como um espelho deformante. Por fim, a última tipologia proposta por Colonna é a da "autoficção intrusiva", na qual "o avatar do escritor é um recitante, um contador ou comentador, enfim um 'narrador-autor' à margem da intriga." (COLONNA, 2014, p. 56).

Essas classificações parecem-nos insuficientes para abarcar o artificio estético adotado por Stigger em seu conto "O livro", porém, se quiséssemos classificá-lo considerando a tipologia de Colonna, descartariamos a "autoficção fantástica" e a "autoficção biográfica", por ambas pressuporem a presença do autor como narrador protagonista. Se o escritor se insere no texto como em uma autobiografia, ele precisa dizer "eu", e esse não é o caso do conto "O livro", cujo narrador em primeira pessoa é o personagem do palestrante. A mesma justificativa explica porque não incluiriamos o conto de Stigger na nomenclatura da "autoficção intrusiva", pois Stigger não aparece como "narradora-autora", mas como personagem. Resta-nos, portanto, analisar o conto pela perspectiva da "autoficção especular", tomando o espelho como a melhor metáfora para tecer nossa investigação.

Segundo Umberto Eco, "O espelho é um fenômeno-limiar, que demarca as fronteiras entre o imaginário e o simbólico" (ECO, 1989, p. 12). A imagem refletida pelo espelho é a de seu próprio observador, de modo que um adulto deveria reconhecer-se a si mesmo naquela projeção. Eco recupera Lacan e seus escritos sobre a fase do espelho para compreender como a relação entre o homem e sua imagem vai sendo ajustada com o passar dos anos e a chegada da maturidade:

Entre os seis e oito meses, a criança se defronta com a própria imagem refletida no espelho. Numa primeira fase confunde a imagem com a realidade, numa segunda fase percebe tratar-se de uma imagem, numa terceira compreende que a imagem refletida é a sua (ECO, 1989, p. 12). 
Mas, questionamo-nos, e se nessa terceira fase o observador não reconhecer aquela imagem como a sua, porém como uma distorção de si mesmo? Um outro perverso e maléfico?

Há, talvez, algo de monstruoso com a duplicação oferecida pelo espelho, como se aquela imagem, percebida pelo espectador como se estivesse dentro do espelho, revelasse um outro. Seria o espelho uma experiência de relação com a alteridade? Com o outro que habita em si mesmo? Esse parece ser o procedimento adotado por Stigger em seus contos autoficcionais: trata-se de uma experiência de duplicação de si, mas, ao ver-se projetada, desdobrada no texto, em seu livro (que seria, desse modo, comparável a um espelho), sua imagem parece debochar dela mesma, como se tivesse se desdobrado em um outro "eu", um eu monstruoso de si mesma.

Ainda segundo Eco, o espelho pode ser comparável a uma prótese: "uma prótese, no sentido exato, é um aparelho que substitui um órgão que falta (membro artificial, dentadura); mas, em um sentido lato, é todo aparelho que aumenta o raio de ação de um órgão" (ECO, 1989, p. 17). Nesse sentido, como uma prótese capaz de intensificar o raio de ação de um certo órgão, o espelho pode acabar provocando enganos perceptivos.

O espelho deformante instaurado por Stigger em "O livro" borra os limites de seu referente: desdobrando-se em outras Veronicas Stigger, a autora real é induzida a ver a si mesma (e também induz seu leitor a vê-la do mesmo modo) como a Veronica que desaparece após enviar um pacote de Montevidéu, cidade que "dizia lembrar a Porto Alegre de sua infância" (STIGGER, 2019, p. 53), ou como a Verônica com acento circunflexo que viaja o mundo para reencenar, ritualisticamente, seu poema "O coração dos homens", ou, ainda, como o eu lírico infantil deste poema que escreve em primeira pessoa para rememorar os episódios traumáticos vividos na escola. Todas essas imagens deformadas de Stigger não remetem ao referente Veronica Stigger, embora, paradoxalmente, também se refiram a ele, em uma situação alucinatória e inesgotável do que "poderia ser". Experiência similar àquela vivida nos parques de diversão, quando temos um espelho deformante diante de nós. Nas palavras de Eco:

\begin{abstract}
O nosso comportamento é então dúplice: por um lado nos divertimos, ou seja, aproveitamos as caracteristicas alucinatórias do canal. Decidimos então aceitar (lucidamente) o fato de termos três olhos, ou uma barriga enorme, ou pernas curtíssimas, assim como se aceita uma fábula. Na verdade, entramos numa espécie de descanso pragmático: aceitamos que os espelhos, que normalmente devem dizer a verdade, não a digam. Mas a suspensão da nossa incredulidade não diz respeito tanto à imagem, quanto à virtude da prótese deformante. O jogo é complexo: por um lado me comporto como se me encontrasse diante de um espelho plano, que diz a verdade, e acho que me devolve uma imagem "irreal" (daquilo que não sou). Se tomo a imagem como correta, ajudo, por assim dizer, o espelho a mentir. O prazer que sinto nesse jogo não é de ordem estritamente semiósica, é de ordem estética (ECO, 1989, p. 27)
\end{abstract}

Lendo os contos autoficcionais da escritora gaúcha é como se estivéssemos diante desse espelho deformante: por um lado, aceitamos a brincadeira instituida e nos divertimos com os jogos especulares criados por uma mente narcísica, aparentemente apenas capaz de dizer "eu" (não é a primeira vez que Stigger insere a si e a seus familiares e amigos em suas narrativas); por outro, ao aceitarmos o pacto ficcional, ao aceitarmos a fábula, encontramos dificuldade em nos desenredar desse jogo perverso, pois, tal como em uma sala de espelhos, cujos reflexos refletem sempre outros reflexos, nos perdemos na indiscernibilidade entre ilusão e realidade.

Stigger parece, pois, reivindicar o primado da ficção. Para ela, tudo é imagem e, portanto, reflexo. Por isso, em um procedimento radical, forja a própria vida, como vimos em "O livro", sem, contudo, se esquecer de maquinar seu início e fim: seu nascimento e morte. Paradoxalmente, o último conto da obra Os anões, publicada pela primeira vez em 2010 pela falecida Cosac Naify, reproduz um fragmento da certidão de nascimento de Verônica ${ }^{3}$ Antonine Stigger. Surpreendente é a revelação, nesse texto, de que

\footnotetext{
3 É importante ressaltar que Stigger representará a si mesma em uma narrativa como Veronica (sem acento circunflexo) apenas no conto "O livro". Nos demais contos autoficcionais analisados neste artigo ("Imagem verdadeira" e "200m²), encontramos sempre a personagem Verônica (com acento circunflexo).
} 
Verônica Antonine Stigger é do sexo masculino (Figura 1). Ora, ao intitular seu texto de "Imagem verdadeira", a escritora subverte, mais uma vez, noções como realidade e ficção, mostrando que "a imagem é 'verdadeira', embora o documento oficial tenha informações 'falsas'" (CERA, [2011]). A pergunta de fundo que se apresenta é a mesma formulada por Jacques Rancière em seu texto "O destino das imagens": "não há mais realidade, apenas imagens?" (RANCIĖRE, 2012, p. 9). Veronica parece responder que sim: em uma sociedade onde tudo é aparência e espetáculo, as imagens operam um jogo duplo entre o real e o simulacro. Nos textos de Stigger, entretanto, prevalece o simulacro, o artifício, o engodo:

Figura 1 - "Imagem verdadeira"

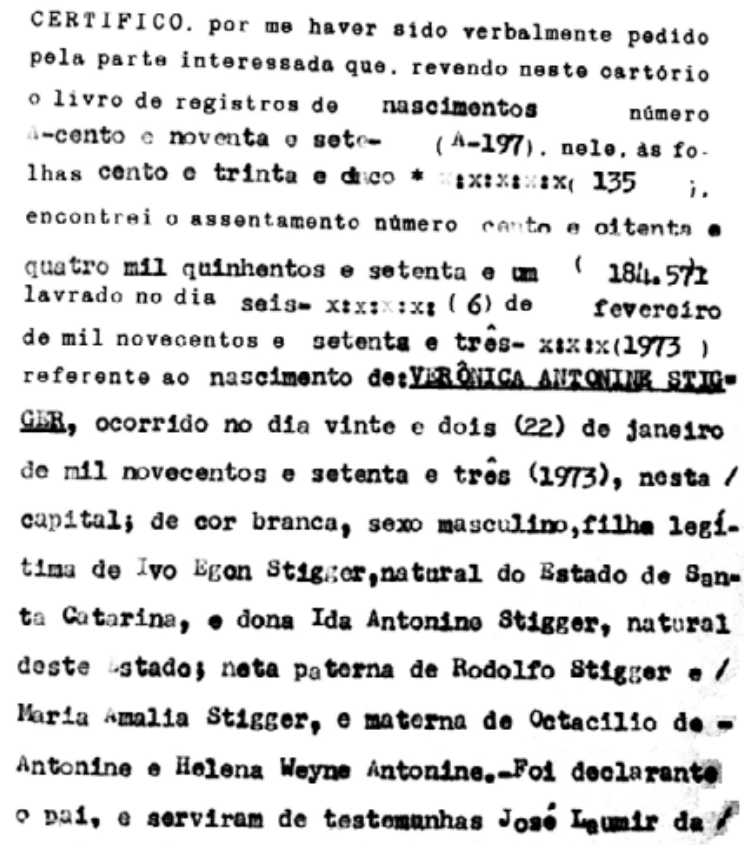

Fonte: STIGGER, 2018, p. 57.

Se a imagem é verdadeira, mas o documento é falso, entramos no território da ficção (ou da autoficção, no caso de Stigger), já que se trata de uma imagem construída, simulada e dissimulada: a técnica e as estratégias ficcionais para moldar a imagem colocam-nos no campo da representação. Esse documento é falso se considerarmos a escritora Veronica Stigger, ser real que habita este mundo, porém, ao considerarmos que se trata da certidão de nascimento ou da "imagem ver- dadeira" de Verônica Antonine Stigger, sujeito de ficção, vemos borrados esses limites. A imagem que aparece no espelho quando nos colocamos diante dele é verdadeira, embora seja somente uma projeção, um reflexo, e não um ser que estaria aprisionado naquele espaço de vidro. $O$ mesmo acontece quando a escritora gaúcha se torna personagem de suas obras: ela se duplica, se ficcionaliza para mostrar que aquela imagem é verdadeira, muito embora não seja ela mesma.

A autoficção, como nos diz Colonna, tem, portanto, algo de especular:

ao pôr em circulação seu nome, nas páginas de um livro do qual já é o signatário, o escritor provoca, quer queira quer não, um fenômeno de duplicação, um reflexo do livro sobre ele mesmo ou uma demonstração do ato criativo que o fez nascer (COLONNA, 2014, p. 55).

Nesse sentido, longe de adotar uma perspectiva autobiográfica, ou baseada na verossimilhança e em dados de sua vida, Stigger evidencia seu próprio processo criativo: a imagem exposta, que em muitos casos aparenta a si mesma, já que, nos contos aqui analisados, estamos diante de personagens escritoras também chamadas de Verônica (ou Veronica) Stigger, é um artifício que evidencia as engrenagens da literatura, que funciona como um laboratório onde a nossa escritora, talvez perversamente, desmonta e monta seus fragmentos, como peças de um quebra-cabeça sem encaixe, formando, assim, uma imagem distorcida de si.

Nesse labirinto textual, o leitor é desafiado a encontrar as peças necessárias para reconstruir a imagem de Verônica, duplo que se apresenta, a cada vez, em um dos livros da escritora real, e, nesse percurso, também se deparar com a sua morte. O miniconto "200m"2" apresenta, como um espetáculo e ironicamente, o suicídio de Verônica, a gaúcha que estava "trifeliz" pela compra de um apartamento novo. Para comemorar a conquista, a personagem, que também era escritora, e o seu marido, Eduardo (mesmo nome do marido da Stigger de carne e osso), convidam amigos para participar de um chá de panela. 0 momento festivo, celebrado pela empolgação de convidados que "estavam encantados com 
a amplitude das peças" (STIGGER, 2018, p. 18), culmina com uma cena espetacular, embora mórbida, planejada por Verônica e seu marido: "No meio da festa, Verônica foi até a cristaleira, pegou a pistola que herdara do avô, colocou-a na boca e disparou" (STIGGER, 2018, p. 18). Esse suicidio, cuja violência fica registrada apenas na parede azul que contrasta com o vermelho dos miolos da personagem, não parece comover ninguém, já que, "como combinado, Eduardo leu um conto que ela deixou - e que, como sempre, ninguém compreendeu" (STIGGER, 2018, p. 18).

O hermetismo da escrita da personagem Verônica confunde-se com sua própria decisão pelo suicídio (suicídio que, aliás, parece ter sido incentivado por seu próprio avô, ao the atribuir como herança uma pistola): se a atitude da personagem não é explicada, pautando-se como um ato performático e teatral, essa gera menos estranhamento do que o conto deixado pela escritora personagem e lido pelo marido Eduardo. No entanto, o fato de não estar mais presente para explicá-lo talvez seja a própria intenção de Verônica, revelando, assim, que a literatura subsiste mesmo quando seu autor (ou sua autora) morreu.

Ao questionar ideias como a de autoria, realidade e verdade, Stigger, em um procedimento jocoso e irônico, projeta-se, especularmente, em seus próprios textos: reconstrói seu nascimento, forja vidas inusitadas para si e arma sua própria morte, desarticulando os referentes de sua linguagem, esvaziando-a de sentido, para que o leitor reconheça a própria Veronica Stigger (intencionalmente sem acento circunflexo agora) como uma obra de ficção.

\section{Especularidade e distorção: considerações finais}

O conto autoficcional de Veronica Stigger mostrou-se, portanto, como um gênero capaz de deformar tanto a narrativa quanto o próprio "eu": ao colocar-se como personagem, Stigger insere-se em seu texto em um relato disparatado e inverossimil, debochando, inclusive, do próprio conceito de "autoficção". Os três contos narcísicos aqui analisados evidenciaram um certo desejo de falar de si, mas, ciente da impossibilidade desse propósito, a escritora gaúcha brinca com os limites entre verdade e ficção ao apresentar um duplo distorcido. Como um espelho deformante, o conto de Stigger desfigura o gênero, assim como seu reflexo textual, escancarando, como se desse gargalhadas na cara do leitor, que tudo não passa de ficção, de "uno scherzo".

Por meio da prática do roubo de palavras alheias e próprias, observamos que Stigger toma o seu nome, além de sua própria produção literária, para subverter as relações impostas entre o gênero e o processo de criação artística. Como uma grande brincadeira, a escritora, que muito já se apropriou de palavras alheias, toma as suas próprias para constituição de novos contos, a exemplo de "O livro"; porém, seu conto narcísico é só uma forma de debochar do leitor, ao colocar em jogo noções como as de gênero e autoria.

Por isso, "A autoficção só faz sentido se lida como show, como espetáculo, ou como gesto" (KLINGER, 2008, p. 26), marcando, justamente, o lado cômico que vigora na contística de Stigger. Se a autoficção pode ser vista como uma tendência da prosa da escritora gaúcha e, em termos mais amplos, da própria ficção brasileira contemporânea, Stigger, ao dessacralizá-la ou desmascará-la, evidencia uma certa exaustão da cultura, da crítica e da literatura para com essa forma de o autor instituir-se como sujeito ficcional. Ao debochar desse gênero revelando certa fadiga para com ele, a autora de Os anões recorre ao riso, por meio da deformação de si e da projeção especular de seus textos, que se inserem uns nos outros como matrioskas, as bonecas russas. Assim, sua prosa assenta-se na exibição de reflexo de reflexos, em um processo infinito de duplicação, simulação e criação de imagens, gêneros textuais e autorias.

\section{Referências}

BARTHES, Roland. O efeito de real. In: BARTHES, Roland. O rumor da língua. Tradução de Mario Laranjeira. São Paulo: Brasiliense, 1988. p. 158-165.

BORGES, Jorge Luis. Prólogo. In: BORGES, Jorge Luis. Ficções. Tradução de Carlos Nejar. Porto Alegre: Editora Globo S.A., 1970. p. XIII-XIV. 
BOSI, Alfredo. Situação e formas do conto brasileiro contemporâneo. In: BOSI, Alfredo. O conto brasileiro contemporâneo. São Paulo: Cultrix, 2015. p. 7-22.

CERA, Flávia Biff. O estranho porvir de Veronica Stigger. In: CONGRESSO INTERNACIONAL DAABRALIC, 12., 2011, Curitiba. Anais [...]. Curitiba: UFPR, 2011. Disponivel em: https://abralic.org.br/eventos/cong2011/AnaisOnline/ resumos/TC1178-1.pdf. Acesso em: 5 fev. 2021.

COLONNA, Vincent. Tipologia da autoficção. In: NORONHA, Jovita Maria Gerheim (org.). Ensaios sobre a autoficção. Traduçaõ de Jovita Maria Gerheim Noronha; Maria Inês Coimbra Guedes. Belo Horizonte: Ed. UFMG, 2014. p. 39-66

DOUBROVSKY, Serge. O último eu. In: NORONHA, Jovita Maria Gerheim (org.). Ensaios sobre a autoficção. Trad. Jovita Maria Gerheim Noronha; Maria Inês Coimbra Guedes. Belo Horizonte: Ed. UFMG, 2014. p. 111-125

ECO, Umberto. Sobre os espelhos. In: ECO, Umberto Sobre os espelhos e outros ensaios. Tradução de Beatriz Borges. Rio de Janeiro: Nova Fronteira, 1989. p. 11-37.

KLINGER, Diana. Escrita de si como performance. Revista brasileira de literatura comparada, [S. I.], n. 12, p. 11-30, 2008. Disponivel em: https://abralic.org.br/downloads/ revistas/1415542249.pdf. Acesso em: 13 fev. 2021.

NORONHA, Jovita Maria Gerheim (org.). Ensaios sobre a autoficção. Tradução de Jovita Maria Gerheim Noronha; Maria Inês Coimbra Guedes. Belo Horizonte: Ed. UFMG, 2014

PIBAROT, Annie (entrevista). Dois eus em confronto: Philippe Lejeune, Philippe Vilain. In: NORONHA, Jovita Maria Gerheim (org.). Ensaios sobre a autoficção. Tradução de Jovita Maria Gerheim Noronha: Maria Inês Coimbra Guedes. Belo Horizonte: Ed. UFMG, 2014. p. 223-242.

PIGLIA, Ricardo. Teses sobre o conto. In: PIGLIA, Ricardo. Formas breves. Tradução de José Marcos Mariani de Macedo. São Paulo: Companhia das Letras, 2004. p. 87-94.

PIGLIA, Ricardo. Novas teses sobre o conto. In: PIGLIA, Ricardo. Formas breves. Tradução de José Marcos Mariani de Macedo. São Paulo: Companhia das Letras, 2004. p. 95-114.

RANCIĖRE, Jacques. O destino das imagens. In: RANCIĖRE, Jacques. O destino das imagens. Tradução de Mônica Costa Netto. Rio de Janeiro: Contraponto, 2012. p. 9-41.

SCHØLLHAMMER, Karl Erik. Ficção brasileira contemporânea. Rio de Janeiro: Civilização Brasileira, 2009.

STIGGER, Veronica. Veronica Stigger e suas estranhas e pequenas histórias. Entrevista concedida a Bruno Dorigatti. 2010. In: SOUZA, Gustavo Ramos de. O espetáculo em minicontos de Os anões, de Veronica Stigger. RevLet - Revista Virtual de Letras, [S. I.], v. 8, n. 2, ago./ dez., 2016. Disponivel em: http://www.revlet.com.br/ artigos/405.pdf. Acesso em: 13 fev. 2021.

STIGGER, Veronica. O coração dos homens. In: STIGGER, Veronica. Sul. 1. ed. São Paulo: Editora 34, 2016. p. 59-80.

STIGGER, Veronica. Os anões. São Paulo: SESI-SP, 2018.
STIGGER, Veronica. O livro. In: STIGGER, Veronica. Sombrio Ermo Turvo. 1. ed. São Paulo: Todavia, 2019. p. 45-53.

SÜSSEKIND, Flora. Objetos verbais não-identificados, Jornal O Globo, 21 set. 2013. Prosa \& Verso. Disponivel em: https://blogs.oglobo.globo.com/prosa/post/ objetos-verbaisnao-identificados-um-ensaio-de-flora-sussekind-510390.html. Acesso em: 13 fev. 2021.

\section{Bruna Fontes Ferraz}

Doutora em Teoria da Literatura e Literatura Comparada pela Universidade Federal de Minas Gerais (UFMG), em Belo Horizonte, MG, Brasil; professora do Centro Federal de Educação Tecnológica de Minas Gerais (CEFET-MG), em Belo Horizonte, MG, Brasil.

\section{Endereço para correspondência}

\section{Bruna Fontes Ferraz}

Centro Federal de Educação Tecnológica de Minas Gerais

Departamento de Linguagem e Tecnologia

Av. Amazonas, 5253

Nova Suiça, 30421-169

Belo Horizonte, MG, Brasil

Os textos deste artigo foram revisados pela Poá Comunicação e submetidos para validação da autora antes da publicação. 